\title{
Effect of nitrogen management and seedling raising methods on the productivity of Aus rice under tidal ecosystem of Bangladesh
}

\author{
Antara Sarker, Swadesh Chandra Samanta, \& Gopal Saha \\ Department of Agronomy, Patuakhali Science and Technology University, Dumki, Patuakhali, \\ Bangladesh-8602
}

\begin{abstract}
The low productivity of Aus rice in the tidal ecosystem of Bangladesh is mainly due to the difficulties in nitrogen $(\mathrm{N})$ management under high tidal water along with unavailability of irrigation water during the onset of rice cultivation. Our present study demonstrated how the productivity of Aus rice could be improved using appropriate seedling raising methods and $\mathrm{N}$ management practices. The study was laid out in split plot design consisting two factors viz., seedling raising methods (wet seed bed and dry seed bed) and $\mathrm{N}$ management practices (six $\mathrm{N}$ treatments) in three replications. Results indicated that both the seedling raising methods and $\mathrm{N}$ management practices had significant effect on all the yield contributing characters of transplanted Aus rice under tidal condition. Specifically, the combination of seedlings raised in wet seed bed and fertilized with urea super granule (USG) at 10 days after transplanting (DAT) i.e., $\mathrm{N}_{3} \mathrm{~W}$ showed the best values for plant height $(110.33 \mathrm{~cm})$, number of effective tillers hill $^{-1}$ (14.60), days required $50 \%$ flowering (53.00 DAT), days to maturity ( 84.33 DAT), panicle length $(23.37 \mathrm{~cm})$, number of filled grain panicle ${ }^{-1}(88.13), 1000-$ grain weight (43.17 g), grain yield $\left(4.62\right.$ tha $\left.^{-1}\right)$, straw yield $\left(6.07\right.$ tha $\left.^{-1}\right)$, biological yield $\left(10.67\right.$ tha $\left.^{-1}\right)$, and harvest index $(43.17 \%)$. However, in considering the productivity/ grain yield, besides $\mathrm{N}_{3} \mathrm{~W}$, the whole urea application at land preparation along with wet seed bed $\left(\mathrm{N}_{1} \mathrm{~W}\right)$ and USG application along with dry seed bed $\left(\mathrm{N}_{3} \mathrm{D}\right)$ also produced statistically similar results $(p<0.01)$ and thus all these three combinations may be practiced for improving productivity and ensuring horizontal expansion of Aus rice in the tidal ecosystem of Bangladesh.
\end{abstract}

\section{Article History}

Received 25 March 2020

Accepted 14 June 2020

\section{Keyword}

Aus rice,

Nitrogen

management,

Wet seed bed,

Dry seed bed,

Tidal ecosystem.

\section{Introduction}

Rice (Oryza sativa L.) is the most important staple food crops for over half of the world's population and over 759.6 Mt of rice was produced globally in 2017 (FAO 2018). Near about $90 \%$ of annual rice is produced and consumed in Asia. The average yield in Asia is low compared to global mean yield (Haider 2018). More than two billion people in Asia are dependent on rice for their livelihood (Xiong et al., 2013). The demand for rice is increasing to meet the demand of rising population. And, the possible way to meet this increases demand by improvement of rice yield per hectare (Liu et al., 2016). In Bangladesh, about 75\% of the total cropped area and over $80 \%$ of the total irrigated area is occupied by rice (BBS, 2013). Thus, rice plays a vital role in the livelihood of the people of Bangladesh. There are 
three rice growing season viz. Aus, Aman \& Boro in Bangladesh which are cultivated during Kharif-1 (April-July), Kharif-2 (July-November) and Rabi (November-April), respectively. After the 1980s, Aus production slowly began to lose priority to the farmers as they shifted to irrigated Boro rice cultivation due to its higher yield (BRRI 2011). The Government of Bangladesh has given top priority for increasing the area and production of Aus rice to reduce the pressure on electricity for irrigation needed for Boro rice production during dry season. Compare to Boro, Aus requires less irrigation and the plan is to cut dependency on the underground water for irrigation and arrest the fall in the water level in the aquifer. Aus rice in this regard can create scope by scaling up production and shed dependency on the underground water (UNB 2017). But the main drawback is the average yield of Aus rice (2.16 $\mathrm{t} \mathrm{ha}^{-1}$ ) which is lower than Aman and Boro rice (BBS 2013). Using the latest high yielding varieties of transplanted Aus rice along with improved cultivation techniques might be the best possible options to meet this productivity gap of Aus rice. Bangladesh occupies most lands of the great Bengal plane of the Ganges Delta with affluent alluvial soils. And, the overall natural climate and geographic condition of Bangladesh is blissful for growing Aus rice. The main problem is insufficient rainfall in April-May with which wet nursery bed preparation and transplanting is very difficult. So, preparation of wet nursery bed and transplant Aus rice seedlings using the tidal water may be a good option. Since water is not easily available and time of Aus planting uncertain, dry nursery bed may be alternative option by the farmers of tidal area. However, till date there is no such comparative study on the yield variability of transplanted rice between wet and dry nursery bed.

Besides, the management of nitrogenous fertilizer (either as basal or top dressing) is difficult due to high depth of water during cultivation period. Nitrogen $(\mathrm{N})$ is the key element in the production of rice. But, the $\mathrm{N}$ management in the tidal areas is always a great challenge. To improve rice yield supplementation of $\mathrm{N}$ fertilizer under most agro-ecosystem has been suggested (Fageria and Santos, 2014). Nitrogen helps to increase rice productivity through improving leaf $\mathrm{N}$ concentration, photosynthetic rate, delaying leaf senescence, and increasing dry matter for grain filling (Hasegawa et al., 1994). Moreover, $\mathrm{N}$ may also play great role in improving panicle size, grain weight and reducing spikelet sterility (Fageria, 2009). Application of $\mathrm{N}$ fertilizer in rice has also been reported to significantly increase the grain and straw $\mathrm{N}$ uptake and $\mathrm{N}$ use efficiency (Hassan et al., 2009). Normally, farmers in the developing countries apply $\mathrm{N}$ in two ways. One is broadcasting of prilled urea (PU), which is the common practice in Bangladesh and another is urea deep placement (UDP) in the form of urea super granule (USG). It has been reported that compared to UDP, the main problem of PU is the $\mathrm{N}$ volatilization loss as ammonia (Rochette et al., 2013). Basically the use efficiency of urea is very low and the recovery of $\mathrm{N}$, especially in wetland rice field rarely exceeds $40 \%$ (De Datta, 1989). However, minimizing of $\mathrm{N}$ losses in the environment was also possible by applying urea to plants through the foliage (Giroux 1984 \& Millard and Robinson 1990). In several researches it has been observed that most of the plants rapidly can absorb liquid urea and hydrolyze the absorbed urea in the cytosol subsequently ensure better assimilation in the plants' system which help to increase $\mathrm{N}$ use efficiency (Wittwer et al. 1963, Nicoulaud and Bloom 1996 and Lam et al. 1996)

At this point, our present study has been designed to find out the effect of suitable $\mathrm{N}$ management practices along with different seedling raising methods viz. wet and dry bed on the yield and yield contributing characters of tidal Aus rice and thus, to unlock the potentials of horizontal expansion of Aus rice cultivation in the coastal areas of Bangladesh. 


\section{Materials and Methods}

\section{Experimental location and climate}

The study was carried out at the Agronomy Field Laboratory of Patuakhali Science and Technology University (PSTU), Patuakhali, Bangladesh from April to August, 2017. The experimental field was located under Ganges Tidal Floodplain Agro-ecological Zone (AEZ) 13. This region occupies an extensive area of coastal tidal floodplain land in the south-west of the country. The area lies at 0.9 to 2.1 meter above mean sea level. The study area was located under the sub-tropical climate, which is specialized by moderately high temperature and heavy rainfall during the Kharif-1 (March to August) and Kharif-2 season (AprilSeptember) and low rainfall with moderately low temperature during Robi season (OctoberMarch).

The experimental field was flooded twice daily by tidal inundation. The magnitude of tidal water depth, flow of water and stagnation period of water depends mainly on the moonmonth, wind speed, wind direction and air pressure that attains peak in May-August (Figure 1). The highest water depth of the field were observed at the beginning and mid of the moonmonth. The data were collected every two days interval from transplanting ( $14^{\text {th }}$ May) to harvesting date $\left(31^{\text {th }}\right.$ July).

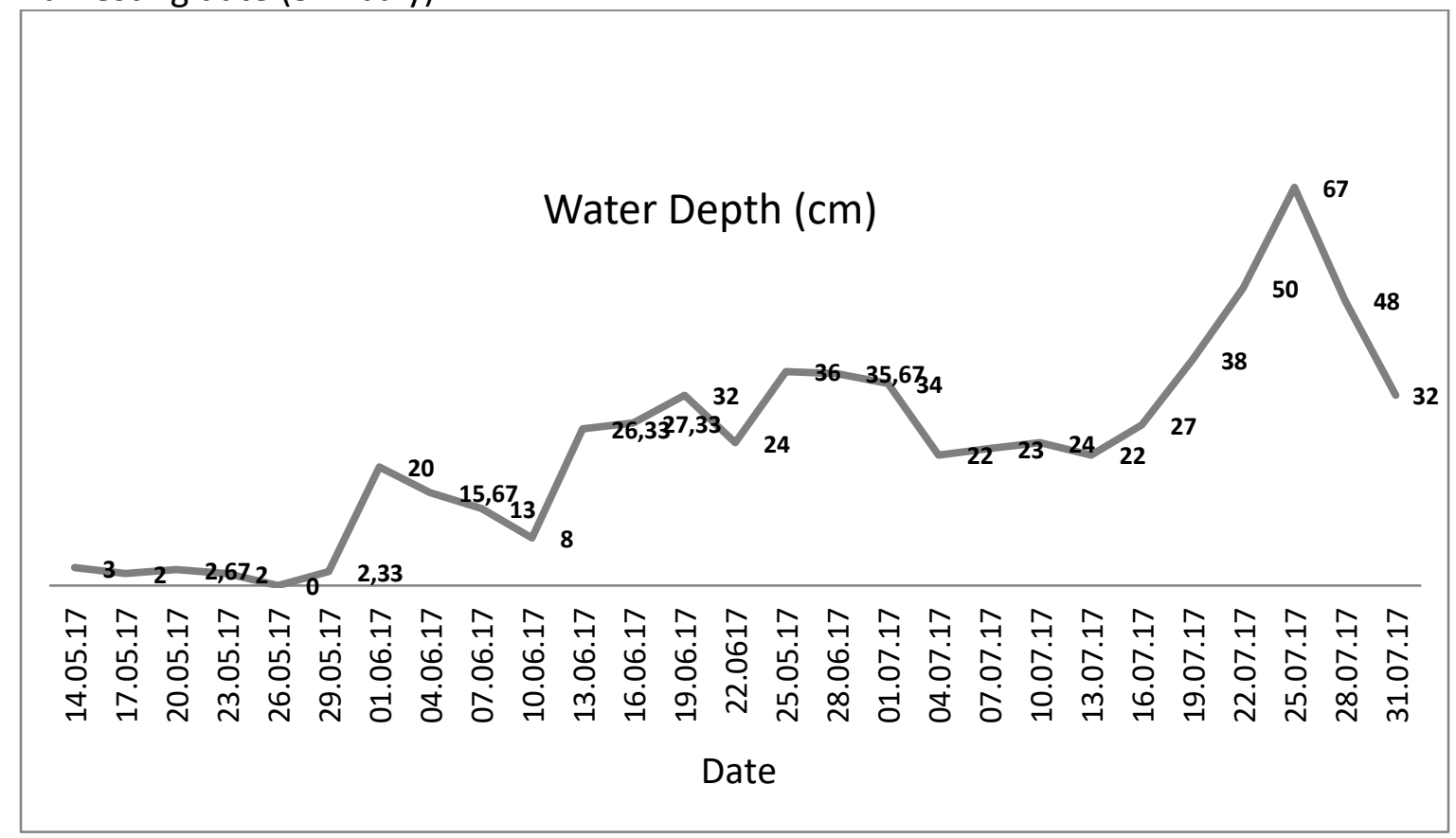

Figure 1. Height of water (in cm) in the experimental field of transplant Aus rice from transplanting to harvesting

\section{Experimental Procedure}

The study was a two factor experiment with three replications where two sets of experimental treatments included in the study as factor-A (six nitrogen management practices) and factor- $B$ (two seedling raising methods) have been presented in Table 1 . The experiment was laid out in a split-plot design where twelve (12) treatment combinations were allocated in 36 plots of $8 \mathrm{~m}^{2}$ size $(5 \mathrm{~m} \times 1.6 \mathrm{~m})$. BRRIdhan55, an Aus rice variety developed by Bangladesh Rice Research Institute (BRRI) was used as experimental materials. 
Table 1. List of treatments used in the experiment

Factor-A: Six (6) nitrogen management practices

$\mathrm{N}_{0}$ : No nitrogen

$\mathrm{N}_{1}$ : Whole urea at land preparation @ 150 $\mathrm{kg} \mathrm{ha}^{-1}$ as recommended dose

$\mathrm{N}_{2}$ : Urea Super Granule (USG) at Land preparation @ $112 \mathrm{~kg} \mathrm{ha}^{-1}$

$\mathrm{N}_{3}$ : USG @ 1.8g (granule) per 4 hill $\left(112 \mathrm{~kg} \mathrm{ha}^{-1}\right)$ at 10 days after transplanting (DAT)

$\mathrm{N}_{4}: 50 \%$ urea of recommended dose $+2 \%$ urea spray at 30, 45 and 60 DAT (105 Kg)

$\mathrm{N}_{5}$ : $50 \%$ urea of recommended dose at land preparation + Magic growth spray at 30, 45 and 60 days

Factor-B: Two (2) seedling raising methods

W: Wet seedbed

D: $\quad$ Dry seedbed

\section{Fertilizer management}

The experimental plots were fertilized as per Fertilizer Recommendation Guide BARC (2012). Besides, different nitrogenous fertilizers were applied following the procedure as mentioned below-

Urea spray: Liquid urea used in the experiment for foliar spray was prepared by mixing $2 \mathrm{~kg}$ of prilled urea in $100 \mathrm{~L}$ of water as per treatment. The urea was sprayed@ 500L/ha of spray volume at 30, 45 and 60 DAT.

Magic growth spray: Magic growth is a solution of different nutrient elements and it contains $10.51 \%$ total nitrogen, $5.58 \%$ phosphorous, $6.33 \%$ potassium, $0.10 \%$ sulphur, $0.16 \%$ zinc, $0.04 \%$ copper, $0.0006 \%$ iron, $0.006 \%$ manganese, $0.25 \%$ boron, $0.07 \%$ calcium and $0.007 \%$ magnesium. The spray volume of magic growth was prepared by mixing fifty $(50) \mathrm{ml}$ magic growth with $1 \mathrm{~L}$ water. This mixture was sprayed @ 500L /ha at 30, 45 and 60 DAT.

Urea Super Granule (USG): USG fertilizer is manufactured from a physical modification of prilled urea (PU) fertilizer. The International Fertilizer Development Center (IFDC) has developed it. Its nature and properties are similar to that of urea but its granule size is bigger and condensed with some conditions for slow hydrolysis. USG is spherical in shape containing $46 \% \mathrm{~N}$ which is similar to that of PU.

\section{Preparation of seedbed and sowing}

Wet seed bed (W): Wet nursery bed was prepared under irrigated condition. The soil was puddled by three ploughing and cross ploughing with cultivator. The sprouted seeds were sown in the prepared seedbeds on 18th April, 2017. The size of seed bed was $15 \mathrm{~m}^{2}$ (length $5 m$ \& width $1.5 \times 2 m)$.

Dry seed bed (D): The land was first ploughed, cross ploughed and then harrowed until a good tilth condition is attained. The seeds were sown in the prepared dry seedbed on 15th April, 2017. The seed bed size was $15 \mathrm{~m}^{2}$.

\section{Data collection and statistical analysis}

Different yield and yield contributing data viz. plant height $(\mathrm{cm})$, number of effective tillers hill ${ }^{-1}$, days to first flowering, days to $50 \%$ flowering, number of non-effective tillers hill ${ }^{-}$ 1 , days to maturity, panicle length $(\mathrm{cm})$, number of filled grains panicle ${ }^{-1}$, number of unfilled grains panicle ${ }^{-1}$, thousand grain weight $(\mathrm{g})$, grain yield $\left(\mathrm{t} \mathrm{ha} \mathrm{a}^{-1}\right)$, straw yield $\left(\mathrm{t} \mathrm{ha} \mathrm{H}^{-1}\right)$, biological yield ( $t \mathrm{ha}^{-1}$ ) and harvest index (\%) were collected and analysis of variance (ANOVA) was calculated with the help of computer software package MSTAT-C program (Russel 1986). The 
mean differences among the treatments were compared by Duncan's Multiple Range Test (DMRT) at 5\% level of significant (Gomez and Gomez 1984).

\section{Results and Discussion}

In our study different nitrogen management practices and seedling raising methods were found to have significant roles on all the yield and yield contributing characters of Aus rice under tidal ecosystem. The results are presented below in respect to different important growth and yield parameters of transplanted Aus rice.

\section{Plant height}

Nitrogen management had significant effect on plant height $(p<0.01$; Figure 2). Among all the $\mathrm{N}$ management treatments, maximum plant height $(109.17 \mathrm{~cm})$ was observed in $\mathrm{N}_{3}$ treatment [USG @ 1.8g (granule) per 4 hill (112kg/ha) at 10 DAT] and the shortest plant (97.73 $\mathrm{cm}$ ) was recorded in case of $\mathrm{N}_{0}$ treatment (without nitrogen) (Figure 2). Our data is also in accordance with llaga and Daya (1989) regarding plant height in response to nitrogenous fertilizers. Plant height was also significantly influenced by seedling raising methods $(p<0.01$; Figure 2) where in case of seedlings raised in wet seed bed were found as longest $(104.23 \mathrm{~cm})$ compared to the seedlings raised in dry seed bed $(99.61 \mathrm{~cm})$. Interaction of nitrogen management and seedling raising methods had significant effect on plant height of Aus rice ( $p<0.01$; Table 2). The maximum plant height $\left(110.33 \mathrm{~cm}\right.$ ) was found in $\mathrm{N}_{3} \mathrm{~W}$ treatment combination i.e., USG at 10 DAT in combination for the seedlings raised in wet bed and the lowest plant height $(94.00 \mathrm{~cm})$ was obtained in $\mathrm{N}_{0} \mathrm{D}$ treatment i.e. without nitrogen in case of the seedlings raised in the dry bed. We also observed highest plant height of $108.00 \mathrm{~cm}$ from the treatment $\mathrm{N}_{3}$ the raised seedlings in dry bed $\left(\mathrm{N}_{3} \mathrm{D}\right)$ which was statistically at par with $\mathrm{N}_{3} \mathrm{~W}$. Using of the urea deep placement technology (USG) has already proven increased yield in several studies (Bandaogo et al., 2015; Alam et al., 2013; Gregory et al., 2010; Mohanty et al., 1999; Savant and Stangel, 1990). Increased plant height might be the response of enhanced availability of nitrogen from USG.
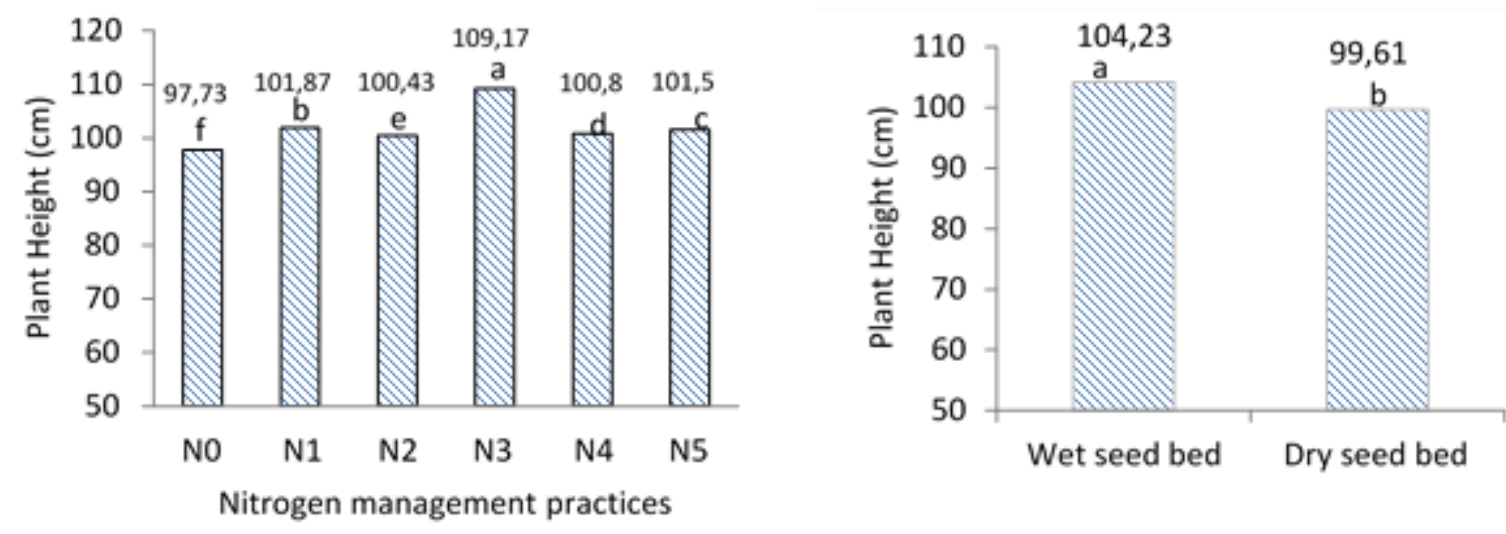

Figure 2. Effect of different nitrogen management practices and seedling raising methods on the plant height of transplant $A u s$ rice. $\left(\mathrm{N}_{0}=\right.$ No nitrogen, $\mathrm{N}_{1}=$ Whole urea at land preparation @ 150kg/ha, $\mathrm{N}_{2}=\mathrm{USG}$ at LP @ $112 \mathrm{~kg} / \mathrm{ha}, \mathrm{N}_{3}=\mathrm{USG} @ 1.8 \mathrm{~g}$ (granule) per 4 hill (112kg/ha) at $10 \mathrm{DAT}, \mathrm{N}_{4}=50 \%$ urea $+2 \%$ urea spray at 30, 45 and $60 \mathrm{DAT}$, $\mathrm{N}_{5}=50 \%$ urea at land preparation + Magic growth spray at 30, 45 and 60 days). Same letter on the bars do not differ significantly as per DMRT $(\mathrm{p}<0.01)$. 
Table 2. Interaction effect of nitrogen management and seedling raising methods on plant height and effective tillers of transplant Aus rice

\begin{tabular}{ccc}
\hline Interaction & Plant height (cm) & No. of effective tillers hill ${ }^{-1}$ \\
\hline$N_{0} W$ & $101.47 \mathrm{bc}$ & $13.13 \mathrm{ab}$ \\
$\mathrm{N}_{1} \mathrm{~W}$ & $103.67 \mathrm{~b}$ & $14.47 \mathrm{a}$ \\
$\mathrm{N}_{2} \mathrm{~W}$ & $103.33 \mathrm{~b}$ & $13.33 \mathrm{ab}$ \\
$\mathrm{N}_{3} \mathrm{~W}$ & $110.33 \mathrm{a}$ & $14.60 \mathrm{a}$ \\
$\mathrm{N}_{4} \mathrm{~W}$ & $103.90 \mathrm{~b}$ & 14.40 \\
$\mathrm{~N}_{5} \mathrm{~W}$ & $102.67 \mathrm{bc}$ & $13.77 \mathrm{ab}$ \\
$\mathrm{N}_{0} \mathrm{D}$ & $94.00 \mathrm{c}$ & $10.73 \mathrm{c}$ \\
$\mathrm{N}_{1} \mathrm{D}$ & $100.07 \mathrm{bc}$ & $13.07 \mathrm{ab}$ \\
$\mathrm{N}_{2} \mathrm{D}$ & $97.53 \mathrm{bc}$ & $12.33 \mathrm{~b}$ \\
$\mathrm{~N}_{3} \mathrm{D}$ & $108.00 \mathrm{ab}$ & $14.20 \mathrm{a}$ \\
$\mathrm{N}_{4} \mathrm{D}$ & $97.70 \mathrm{bc}$ & $11.93 \mathrm{bc}$ \\
$\mathrm{N}_{5} \mathrm{D}$ & $100.33 \mathrm{bc}$ & $13.33 \mathrm{ab}$ \\
\hline Significance level & $* *$ & $* *$ \\
$\mathrm{CV}$ (\%) & 4.30 & 8.85
\end{tabular}

Note: In a column, figures with same letter or without letter do not differ significantly as per $\mathrm{DMRT}^{\prime}{ }^{\prime * * \prime}=$ Significant at $1 \% ; \mathrm{N}_{0}=$ No nitrogen, $\mathrm{N}_{1}=$ Whole urea at land preparation @ $150 \mathrm{~kg} / \mathrm{ha}, \mathrm{N}_{2}=$ USG at LP @ $112 \mathrm{~kg} / \mathrm{ha}, \mathrm{N}_{3}=$ USG @ 1.8g (granule) per 4 hill (112kg/ha) at 10 DAT, $\mathrm{N}_{4}=50 \%$ urea $+2 \%$ urea spray at 30,45 and 60 DAT, $\mathrm{N}_{5}=50 \%$ urea at land preparation + Magic growth spray at 30, 45 and 60 days. $W=$ wet seed bed and $D=D r y$ seed bed; CV $(\%)=$ Percent coefficient of variation.

\section{Effective tillers hill-1}

In case of effective tillers per hill, the effect of different $\mathrm{N}$ management options were highly significant $(p<0.01$; Figure 3$)$. The maximum number of effective tillers hill $^{-1}(14.40)$ was observed from the application of USG at 10 DAT $\left(\mathrm{N}_{3}\right)$ and the lowest number of effective tillers hill ${ }^{-1}$ (11.93) was found from no nitrogen treatment $\left(N_{0}\right)$. Adequacy of nitrogen from USG probably favored the cellular activity during tiller formation and development, which led to increased number of effective tillers hill ${ }^{-1}$. 

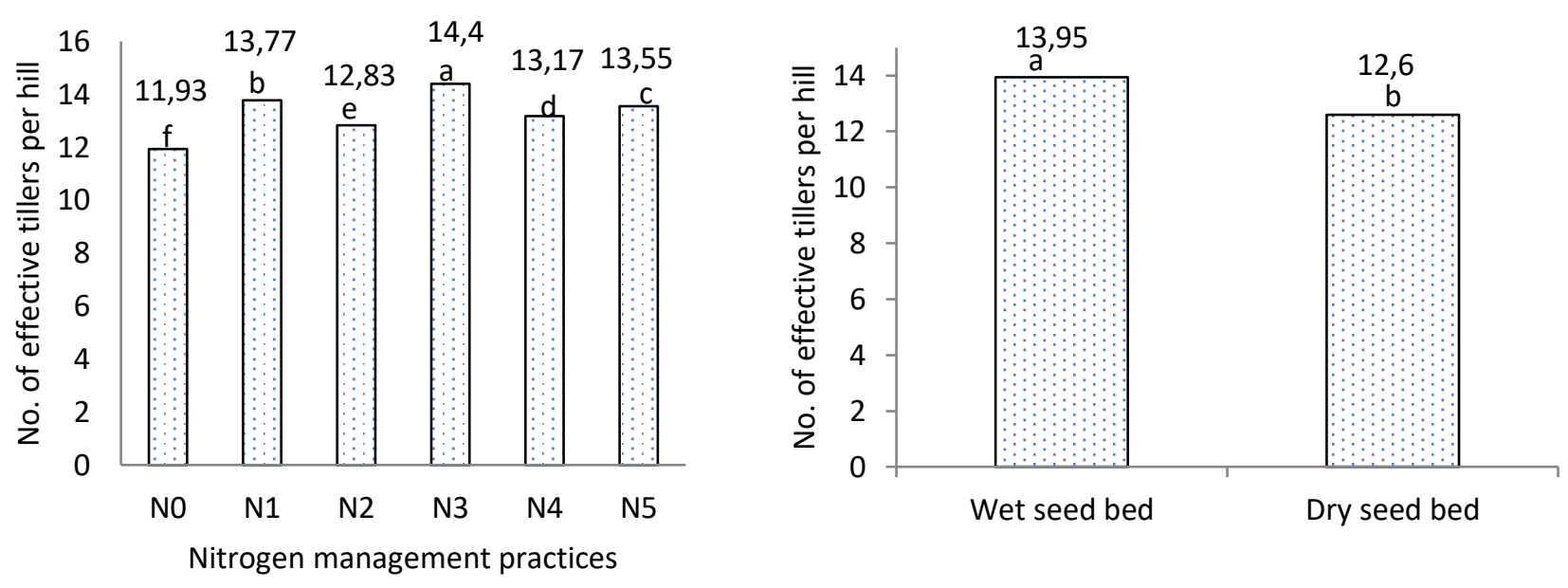

Figure 3. Effect of different nitrogen management practices and seedling raising methods on effective tillers hill-1 of transplant Aus rice. ( $N 0=$ No nitrogen, N1=Whole urea at land preparation @ 150kg/ha, N2=USG at LP @ 112 kg/ha, N3= USG @ 1.8g (granule) per 4 hill $(112 \mathrm{~kg} / \mathrm{ha})$ at $10 \mathrm{DAT}, \mathrm{N} 4=50 \%$ urea $+2 \%$ urea spray at 30, 45 and $60 \mathrm{DAT}, \mathrm{N} 5=50 \%$ urea at land preparation + Magic growth spray at 30, 45 and 60 days). Same letter on the bars do not differ significantly as per DMRT $(p<0.01)$.

Ahmed et al. (2005) also reported that number of effective tillers hill ${ }^{-1}$ increased with the better management of nitrogen. Again, between the two seedling raising methods the number of effective tillers hill ${ }^{-1}$ was also significantly influenced. In case of wet seed bed raised seedling the highest number of effective tillers was recorded (13.95) while this number in case of dry seed bed raised seedlings was 12.60 (Figure 3). The interaction effect of nitrogen management and seedling raising method on number of effective tillers hill ${ }^{-1}$ was significant (Table 2). The number of effective tillers hill ${ }^{-1}$ ranged from 10.73 to 14.60 over the treatments. The highest number of effective tillers hill ${ }^{-1}(14.60)$ was obtained with $\mathrm{N}_{3} \mathrm{~W}$ which was statistically similar to $\mathrm{N}_{4} \mathrm{~W}$ and $\mathrm{N}_{1} \mathrm{~W}$ and the lowest number of effective tillers hill-1 (10.73) with $\mathrm{N}_{0} \mathrm{D}$. Increased $\mathrm{N}$ absorption had great role in increasing number of tillers per square meter (Yoshida et al. 1972).

\section{Days to $50 \%$ flowering and maturity}

Different $\mathrm{N}$ management practices had significant effect on flowering and maturity of transplant Aus rice var. BRRIdhan55 ( $p<0.05$; Table 3 ). The lowest days required for $50 \%$ flowering and maturity (50.50 and 78.33 DAT, respectively) were observed in the plants treated with $\mathrm{N}_{4}$ (50\% urea $+2 \%$ urea spray at 30, 45 and 60 DAT) while highest days were recorded from the treatment $\mathrm{N}_{3}$ (USG at 10 DAT) treated plots which were 52.50 and 82.50 DAT, respectively. In case of the two seedling raising methods, we observed significant variation for days to $50 \%$ flowering $(p<0.05$; Table 4 ) which was 51.83 DAT in wet seed bed seedlings and 51.07 DAT in the dry seed bed seedlings. Nitrogen management and seedling raising methods had significant effect on time required for $50 \%$ flowering ( $p<0.01$; Table 5 ). The treatment combinations of $\mathrm{N}_{4} \mathrm{D}\left(\mathrm{N}_{4}=50 \%\right.$ urea $+2 \%$ urea spray at 30,45 and 60 DAT with dry seedbed) and $\mathrm{N}_{5} \mathrm{D}$ (50\% urea at land preparation + Magic growth spray at 30, 45 and 60 DAT with dry seedbed) required the lowest days to $50 \%$ flowering ( $50.33 \mathrm{DAT}$ ). The highest time period for $50 \%$ flowering was required in case of treatment combination $\mathrm{N}_{3} \mathrm{~W}(53.00$ DAT). We also found significant variation in attaining maturity due to interaction between nitrogen management and seedling raising method (Table 5). $\mathrm{N}_{4} \mathrm{~W}$ required the lowest 
duration for $80 \%$ maturity (78.00 DAT) and $\mathrm{N}_{3} \mathrm{~W}$ needed the longest duration (84.33 DAT). The level of nitrogen in rice field might influence the flower initiation and maturity of T. Aus rice. The flowering and maturity dates were significantly influenced by different $N$ management in several studies (Rahman et al. 2016; Halder 2013 and Rahman et al. 2005). 
Table 3. Effect of nitrogen management practices on different yield and yield contributing attributes of transplant Aus rice

\begin{tabular}{|c|c|c|c|c|c|c|c|c|c|c|}
\hline Treatment & $\begin{array}{c}\text { Days to } \\
50 \% \\
\text { flowering }\end{array}$ & $\begin{array}{l}\text { Days to } \\
\text { Maturity }\end{array}$ & $\begin{array}{l}\text { No. of } \\
\text { filled } \\
\text { grains } \\
\text { panicle }\end{array}$ & $\begin{array}{l}\text { No. of } \\
\text { unfilled } \\
\text { grains } \\
\text { panicle }\end{array}$ & $\begin{array}{l}\text { Panicle } \\
\text { length } \\
\text { (cm) }\end{array}$ & $\begin{array}{l}1000- \\
\text { seed } \\
\text { weight } \\
\text { (g) }\end{array}$ & $\begin{array}{l}\text { Grain } \\
\text { yield } \\
\text { (t/ha) }\end{array}$ & $\begin{array}{l}\text { Straw } \\
\text { yield } \\
\text { (t/ha) }\end{array}$ & $\begin{array}{l}\text { Biological } \\
\text { yield (t/ha) }\end{array}$ & $\begin{array}{c}\text { Harvest } \\
\text { index (\%) }\end{array}$ \\
\hline $\mathrm{N}_{0}$ & $51.33 \mathrm{~b}$ & $79.67 \mathrm{f}$ & $55.80 \mathrm{f}$ & $27.40 \mathrm{a}$ & $19.98 \mathrm{f}$ & $19.98 \mathrm{f}$ & $2.94 \mathrm{f}$ & $5.07 \mathrm{f}$ & $8.01 \mathrm{f}$ & $35.32 \mathrm{f}$ \\
\hline $\mathrm{N}_{1}$ & $51.50 \mathrm{~b}$ & $80.67 \mathrm{~b}$ & $65.27 \mathrm{~b}$ & $24.47 d$ & $21.78 \mathrm{~b}$ & $20.18 b$ & $3.96 \mathrm{~b}$ & $5.76 \mathrm{~b}$ & $9.66 \mathrm{~b}$ & $40.58 \mathrm{~b}$ \\
\hline $\mathrm{N}_{2}$ & $51.83 \mathrm{~b}$ & $80.83 \mathrm{c}$ & $61.70 \mathrm{e}$ & $25.63 \mathrm{~b}$ & $20.62 \mathrm{e}$ & 20.05 e & $3.38 \mathrm{e}$ & $5.41 \mathrm{e}$ & $8.78 \mathrm{e}$ & 38.33 e \\
\hline $\mathrm{N}_{3}$ & $52.50 \mathrm{a}$ & $82.50 \mathrm{a}$ & $78.20 \mathrm{a}$ & $20.60 \mathrm{f}$ & $22.70 \mathrm{a}$ & $20.32 \mathrm{a}$ & $4.23 \mathrm{a}$ & $5.88 a$ & $10.10 \mathrm{a}$ & $41.65 \mathrm{a}$ \\
\hline $\mathrm{N}_{4}$ & $50.50 \mathrm{~d}$ & 78.33 e & $62.00 \mathrm{~d}$ & $25.23 \mathrm{c}$ & $21.33 \mathrm{~d}$ & $20.12 d$ & $3.60 \mathrm{~d}$ & $5.53 d$ & $9.13 d$ & $39.32 \mathrm{~d}$ \\
\hline $\mathrm{N}_{5}$ & $51.00 \mathrm{c}$ & $78.67 d$ & $63.60 \mathrm{c}$ & 23.37 e & $21.45 c$ & $20.15 c$ & $3.74 \mathrm{c}$ & $5.66 \mathrm{c}$ & $9.38 \mathrm{c}$ & $39.83 \mathrm{c}$ \\
\hline Significance level & $*$ & $*$ & $* *$ & $* *$ & $* *$ & $*$ & $* *$ & $* *$ & $* *$ & $* *$ \\
\hline CV (\%) & 2.05 & 2.88 & 7.85 & 8.85 & 5.10 & 3.49 & 8.97 & 7.55 & 7.13 & 3.75 \\
\hline
\end{tabular}

Note: In a column, figures with same letter or without letter do not differ significantly as per DMRT; ${ }^{* \prime}$ and ${ }^{* * \prime}=$ Significant at 5 and $1 \%$, respectively; $\mathrm{N}_{0}=$ No nitrogen, $\mathrm{N}_{1}=$ Whole urea at land preparation @ $150 \mathrm{~kg} / \mathrm{ha}, \mathrm{N}_{2}=$ USG at LP @ $112 \mathrm{~kg} / \mathrm{ha}, \mathrm{N}_{3}=$ USG @ $1.8 \mathrm{~g}$ (granule) per 4 hill $(112 \mathrm{~kg} / \mathrm{ha})$ at $10 \mathrm{DAT}, \mathrm{N}_{4}=50 \%$ urea urea $+2 \%$ urea spray at 30, 45 and $60 \mathrm{DAT}, \mathrm{N}_{5}=50 \%$ urea at land preparation + Magic growth spray at 30 , 45 and 60 days. CV (\%) = Percent coefficient of variation 


\section{Number of filled grains panicle ${ }^{-1}$}

Nitrogen management showed significant variation in the number of filled grains panicle $^{-1}(p<0.01$; Table 3$)$. The highest number of filled grains panicle ${ }^{-1}(78.20)$ was obtained from the $\mathrm{N}_{3}$ i.e., USG at 10 DAT and the lowest number of filled grains panicle ${ }^{-1}(55.80)$ was obtained from the no urea treated plot. This finding is in contrast with the findings of Rajarathinam and Balasubramanivan, (1999) where they found application of $\mathrm{N}$ increased number of filled grains panicle ${ }^{-1}$. The average number of filled grains panicle ${ }^{-1}$ was found significantly different in seedling raising method ( $<<0.01$; Table 4$)$. The highest number of filled grains was recorded in the wet seed bed (71.07) and lowest filled grains were in dry seed bed (57.79). Interaction effect between nitrogen management and seedling raising method had positive effect on filled grains panicle ${ }^{-1}$ (Table 5$)$. The highest number of filled grains (88.13) was obtained from $\mathrm{N}_{3} \mathrm{~W}$ i.e., when USG applied at 10 DAT in combination with the seedlings raised in wet bed and the lowest number of filled grains panicle ${ }^{-1}(50.33)$ was obtained from $\mathrm{N}_{0}$ D i.e. without nitrogen in case of the seedlings raised in the dry bed. Our result suggests that highest number of grains panicle ${ }^{-1}$ might be the response of enhanced availability of nitrogen from USG especially when it applied at 10 DAT. Subsequently, higher available $\mathrm{N}$ might results more photo assimilates and thus produced more dry matter accumulation in the panicle. These findings are also consistent with the findings of other researchers (Alam et al., 2013; Bandaogo et al., 2014; Gregory et al., 2010).

\section{Number of unfilled grains panicle ${ }^{-1}$}

The number of unfilled grains per panicle was significantly different in the nitrogen management (Table 3). The maximum number of unfilled grains per panicle (27.40) was counted in case of no nitrogen and the minimum number of unfilled grains panicle $(20.60)$ was counted in the $\mathrm{N}_{3}$ i.e., USG at 10 DAT. Nitrogen took part both in grain formation and development and for this reason number of grains per panicle increased with adequate $\mathrm{N}$ levels. This result is in conformity with Halder (2013) and Nori et al., (2008). In case of seedling raising methods, number of unfilled grains per panicle was higher in wet seed bed (24.46) and minimum unfilled grains per panicle in dry seed bed (24.44; Table 4). Number of unfilled grains per panicle was found to be significantly affected by interaction effect of nitrogen management and seedling raising method (Table 5). The highest (28.73) number of unfilled grains per panicle was recorded under the $\mathrm{N}_{4} \mathrm{~W}$ that was statistically at par with $\mathrm{N}_{2} \mathrm{D}(28.67)$ and $\mathrm{N}_{0} \mathrm{~W}$ (28.40) whereas the lowest number of unfilled grains per panicle (19.87) was counted in the treatment combination $\mathrm{N}_{3} \mathrm{~W}$.

\section{Panicle length $(\mathrm{cm})$}

The panicle length was significantly affected by nitrogen management practices $(p<0.01$, Table 3). The maximum panicle length $(22.70 \mathrm{~cm})$ was observed in USG @ $112 \mathrm{~kg} / \mathrm{ha}$ at 10 DAT and the lowest $(19.98 \mathrm{~cm})$ panicle length was obtained from without nitrogen $\left(\mathrm{N}_{0}\right)$. The variation in panicle length due to the improved management of $\mathrm{N}$ was also reported by Parvin (2012). In our study, both of the seedling raising methods had significant effect on the panicle length ( $p<0.01$; Table 4) where highest length of $22.08 \mathrm{~cm}$ was recorded in wet seedbed compared to plants raised in dry seedbed $(20.54 \mathrm{~cm})$. Again panicle length was also influenced significantly in case of the interaction effect of nitrogen management practices and seedling raising methods $(p<0.05$; Table 5$)$. The longest panicle $(23.37 \mathrm{~cm})$ was obtained from $\mathrm{N}_{3} \mathrm{~W}$ and the shortest panicle $(19.27 \mathrm{~cm})$ was obtained from the $\mathrm{N}_{2} \mathrm{D}$ which was statistically similar to $\mathrm{N}_{0} \mathrm{D}(19.43 \mathrm{~cm})$. 
Table 4. Effect of seedling raising method on yield and yield contributing attributes of transplant Aus rice

\begin{tabular}{|c|c|c|c|c|c|c|c|c|c|c|}
\hline $\begin{array}{l}\text { Seedling raising } \\
\text { method }\end{array}$ & $\begin{array}{c}\text { Days to } \\
50 \% \\
\text { flowering }\end{array}$ & $\begin{array}{l}\text { Days to } \\
\text { Maturity }\end{array}$ & $\begin{array}{l}\text { No. of } \\
\text { filled } \\
\text { grains } \\
\text { panicle }\end{array}$ & $\begin{array}{l}\text { No. of } \\
\text { unfilled } \\
\text { grains } \\
\text { panicle }^{-1}\end{array}$ & $\begin{array}{c}\text { Panicle } \\
\text { length } \\
\text { (cm) }\end{array}$ & $\begin{array}{l}\text { 1000- } \\
\text { seed } \\
\text { weight } \\
\text { (g) }\end{array}$ & $\begin{array}{l}\text { Grain } \\
\text { yield } \\
\text { (t/ha) }\end{array}$ & $\begin{array}{c}\text { Straw } \\
\text { yield } \\
\text { (t/ha) }\end{array}$ & $\begin{array}{c}\text { Biological } \\
\text { yield (t/ha) }\end{array}$ & $\begin{array}{c}\text { Harvest } \\
\text { index (\%) }\end{array}$ \\
\hline $\begin{array}{c}\text { Wet } \\
\text { seedbed (W) }\end{array}$ & 51.83 & $80.39 a$ & $71.07 \mathrm{a}$ & $24.46 \mathrm{a}$ & $22.08 \mathrm{a}$ & $20.42 \mathrm{a}$ & $3.93 \mathrm{a}$ & $5.70 \mathrm{a}$ & $9.61 \mathrm{a}$ & $40.32 \mathrm{a}$ \\
\hline $\begin{array}{c}\text { Dry } \\
\text { seedbed (D) }\end{array}$ & 51.07 & $79.83 b$ & $57.79 b$ & $24.44 b$ & $20.54 b$ & $19.84 \mathrm{~b}$ & $3.35 b$ & $5.41 b$ & $8.74 \mathrm{~b}$ & $38.02 b$ \\
\hline Significance level & NS & $*$ & $* *$ & $* *$ & $* *$ & $*$ & $* *$ & $*$ & $* *$ & $* *$ \\
\hline CV $(\%)$ & 2.05 & 2.88 & 7.85 & 8.85 & 5.10 & 3.49 & 8.97 & 7.55 & 7.13 & 3.75 \\
\hline
\end{tabular}

Note: In a column, figures with same letter or without letter do not differ significantly as per DMRT; ${ }^{* \prime}$ and ${ }^{\prime * * \prime}=$ Significant at 5 and $1 \%$, respectively, NS= Non-significant; CV (\%) = Percent coefficient of variation 


\section{Thousand (1000)-seed weight (gm)}

The effect of nitrogen management was significant in respect of 1000-grain weight of T. Aus rice ( $p<0.05$; Table 3$)$. The highest 1000 -grain weight $(20.32 \mathrm{~g})$ was obtained from the treatment $\mathrm{N}_{3}$ and the lowest 1000-grain weight (19.98g) was found in control $\left(\mathrm{N}_{0}\right)$. This possibly happened due to the uptake of $\mathrm{N}$ by root of the rice plant that influenced the photosynthesis process and subsequently storage of starch in sink cell such as grain. USG provide the highest amount of available $\mathrm{N}$ in the field and created a chance to fill the grain properly. Hossain and Islam (2008) also reported the variation in 1000-grain weight due to the more availability of $\mathrm{N}$ in soil. Chaturvedi (2005) observed that $\mathrm{N}$ play important role in increasing protein percentage, which in turn increased the grain weight. The weight of $1000-$ grains was also significantly influenced $(p<0.05$; Table 4$)$ by the seedling raising method where the seedling raised in wet bed gave higher 1000 -grain weight $(20.42 \mathrm{~g})$ over dry bed method $(19.84 \mathrm{~g})$. Further, the interaction effect between nitrogen management and seedling raising method gave significant variation regarding the weight of 1000 -grains $(p<0.05$; Table 5$)$. The treatment combination $\mathrm{N}_{2} \mathrm{~W}$ gave highest 1000 -grain weight (20.63 g) which was statistically similar with $\mathrm{N}_{1} \mathrm{~W}, \mathrm{~N}_{3} \mathrm{~W}, \mathrm{~N}_{4} \mathrm{~W}, \mathrm{~N}_{5} \mathrm{~W}, \mathrm{~N}_{3} \mathrm{D}, \mathrm{N}_{4} \mathrm{D}$ and $\mathrm{N}_{5} \mathrm{D}$. The lowest weight of 1000 -grains (19.47 g) was obtained from $\mathrm{N}_{2} \mathrm{D}$

\section{Grain yield}

Grain yield was significantly influenced $(p<0.01)$ by nitrogen management practices (Table 3). By USG @ $112 \mathrm{~kg} /$ ha at 10 DAT $\left(\mathrm{N}_{3}\right)$ produced the highest grain yield $\left(4.23 \mathrm{t} \mathrm{ha}^{-1}\right)$ which was followed by the treatments $N_{1}, N_{5}, N_{4}, N_{2}$ and $N_{0}$. The lowest grain yield (2.94 $t$ ha$\left.{ }^{1}\right)$ was recorded from without nitrogen $\left(N_{0}\right)$. The highest grain yield might be due to the resultant effect of highest number of effective tillers per hill and highest number of grains per panicle as obtained in the treatment $N_{3}$. Miah et al. (2006) stated that USG increased an average of $20 \%$ rice yield in tidal flooded condition. Grain yield variations due to fertilizer management were also reported by Shah et al. (2013), Das (2011), Jun et al. (2011) and Tahura (2011). Grain yield was also significantly influenced by seedling raising methods (Table 4). The highest grain yield $\left(3.93 \mathrm{t} \mathrm{ha}^{-1}\right)$ was obtained from the Wet seed bed compared to the yield ( 3.35 tha $^{-1}$ ) obtained by the seedlings raised in dry seed bed. Interaction between nitrogen management and seedling raising method also played positive role in promoting grain yield of transplant Aus rice. Highest grain yield of $4.62 \mathrm{t} \mathrm{ha}^{-1}$ was from the treatment combination $\mathrm{N}_{3} \mathrm{~W}$ which was statistically at par with $\mathrm{N}_{1} \mathrm{~W}$ (the whole urea application at land preparation along with wet seed bed) and $\mathrm{N}_{3} \mathrm{D}$ (USG application along with dry seed bed) and the lowest grain yield was recorded in $\mathrm{N}_{0} \mathrm{D}\left(2.56 \mathrm{t} \mathrm{ha}^{-1}\right.$; Table 5).

\section{Straw yield}

Straw yield was significantly $(p<0.01)$ affected by the nitrogen management (Table 3 ). The highest straw yield $\left(5.88 \mathrm{t} \mathrm{ha}^{-1}\right)$ was obtained from the plot applied with USG $112 \mathrm{~kg} / \mathrm{ha}$ at $10 \mathrm{DAT}\left(\mathrm{N}_{3}\right)$ and the least straw yield $\left(5.07 \mathrm{t} \mathrm{ha}^{-1}\right)$ was obtained from the no urea treated plot $\left(\mathrm{N}_{0}\right)$. Availability of nitrogen at vegetative phase during the initiation of primary, secondary and tertiary tillers resulted in increased accumulation of dry matter which probably favored highest straw yield. Significant variation in straw yield was also reported by Shah et al. (2013) and Das (2011). Straw yield was significantly influenced $(p<0.05)$ by the seedling raising method (Table 4). The highest straw yield $\left(5.70\right.$ tha $\left.^{-1}\right)$ was obtained from the wet seed bed compared to $\left(5.11 \mathrm{t} \mathrm{ha}^{-1}\right)$ dry seed bed. Again, the highest straw yield (6.07 tha-1) was recorded from the interaction of seedling raised in wet seed bed and 
Table 5. Interaction effect of nitrogen management and seedling raising method on yield and yield contributing attributes

of transplant Aus rice

\begin{tabular}{|c|c|c|c|c|c|c|c|c|c|c|}
\hline $\begin{array}{l}\text { Treatment } \\
\text { combination }\end{array}$ & $\begin{array}{l}\text { Days to } 50 \% \\
\text { flowering }\end{array}$ & $\begin{array}{l}\text { Days to } \\
\text { Maturity }\end{array}$ & $\begin{array}{l}\text { No. of } \\
\text { filled } \\
\text { grains } \\
\text { panicle }\end{array}$ & $\begin{array}{l}\text { No. of } \\
\text { unfilled } \\
\text { grains } \\
\text { panicle }\end{array}$ & $\begin{array}{c}\text { Panicle } \\
\text { length } \\
\text { (cm) }\end{array}$ & $\begin{array}{c}1000- \\
\text { seed } \\
\text { weight } \\
\text { (g) }\end{array}$ & $\begin{array}{l}\text { Grain } \\
\text { yield } \\
\text { (t/ha) }\end{array}$ & $\begin{array}{l}\text { Straw } \\
\text { yield } \\
\text { (t/ha) }\end{array}$ & $\begin{array}{c}\text { Biological } \\
\text { yield (t/ha) }\end{array}$ & $\begin{array}{c}\text { Harvest } \\
\text { index (\%) }\end{array}$ \\
\hline NoW & $51.67 \mathrm{ab}$ & $79.67 \mathrm{bc}$ & $61.27 c$ & $28.40 \mathrm{a}$ & $20.53 b$ & $20.17 a b$ & $3.32 \mathrm{bc}$ & $5.25 b c$ & $8.57 b c$ & $36.23 b c$ \\
\hline $\mathrm{N}_{1} \mathrm{~W}$ & $51.67 \mathrm{ab}$ & $80.33 a b$ & 77.07 b & $22.73 b c$ & $22.80 \mathrm{ab}$ & $20.37 a b$ & $\begin{array}{c}4.24 \\
a b\end{array}$ & $5.91 \mathrm{ab}$ & $10.13 a b$ & $41.77 \mathrm{ab}$ \\
\hline $\mathrm{N}_{2} \mathrm{~W}$ & $52.33 \mathrm{ab}$ & $81.67 a b$ & $63.80 \mathrm{bc}$ & $22.60 \mathrm{bc}$ & $21.97 \mathrm{ab}$ & $20.63 a$ & $3.77 \mathrm{bc}$ & $5.66 \mathrm{~b}$ & $9.42 a b$ & $39.93 \mathrm{bc}$ \\
\hline $\mathrm{N}_{3} \mathrm{~W}$ & $53.00 \mathrm{a}$ & $84.33 \mathrm{a}$ & $88.13 \mathrm{a}$ & $19.87 \mathrm{c}$ & $23.37 \mathrm{a}$ & $20.50 a b$ & $4.62 \mathrm{a}$ & $6.07 a$ & $10.67 \mathrm{a}$ & $43.17 \mathrm{a}$ \\
\hline $\mathrm{N}_{4} \mathrm{~W}$ & $50.67 \mathrm{bc}$ & $78.00 \mathrm{c}$ & $66.13 b c$ & $28.73 \mathrm{a}$ & $21.80 \mathrm{ab}$ & $20.47 a b$ & $3.78 \mathrm{bc}$ & $5.60 \mathrm{~b}$ & $9.38 a b$ & $40.23 b$ \\
\hline $\mathrm{N}_{5} \mathrm{~W}$ & $51.67 \mathrm{ab}$ & $78.33 \mathrm{bc}$ & 70.00 & $24.40 \mathrm{~b}$ & $22.03 a b$ & $20.40 a b$ & $3.85 b c$ & $5.68 \mathrm{~b}$ & $9.50 \mathrm{ab}$ & $40.60 \mathrm{ab}$ \\
\hline $\mathrm{N}_{0} \mathrm{D}$ & $51.00 \mathrm{~b}$ & 79.67 bc & $50.33 d$ & $26.40 \mathrm{ab}$ & $19.43 \mathrm{c}$ & $19.80 \mathrm{bc}$ & $2.56 \mathrm{c}$ & $4.89 c$ & $7.45 \mathrm{c}$ & $34.40 \mathrm{c}$ \\
\hline $\mathrm{N}_{1} \mathrm{D}$ & $51.33 a b$ & $81.00 a b$ & $53.47 \mathrm{~cd}$ & $26.20 \mathrm{ab}$ & $20.77 b$ & $20.00 \mathrm{~b}$ & $3.67 \mathrm{~b}$ & $5.61 \mathrm{~b}$ & $9.18 \mathrm{~b}$ & $39.40 \mathrm{bc}$ \\
\hline $\mathrm{N}_{2} \mathrm{D}$ & $51.33 a b$ & $80.00 \mathrm{~b}$ & $59.60 \mathrm{~cd}$ & $28.67 \mathrm{a}$ & $19.27 \mathrm{c}$ & $19.47 \mathrm{C}$ & $2.99 b c$ & $5.15 b c$ & $8.14 b c$ & $36.73 b c$ \\
\hline $\mathrm{N}_{3} \mathrm{D}$ & $52.00 \mathrm{ab}$ & $80.67 b c$ & $68.27 b c$ & $21.33 \mathrm{bc}$ & $22.03 a b$ & $20.13 a b$ & $\begin{array}{c}3.83 \\
a b\end{array}$ & $5.70 \mathrm{ab}$ & $9.53 a b$ & $40.13 b$ \\
\hline $\mathrm{N}_{4} \mathrm{D}$ & $50.33 c$ & $78.67 \mathrm{bc}$ & $57.87 \mathrm{~cd}$ & $21.73 b c$ & $20.87 a b$ & $19.77 \mathrm{bc}$ & $3.42 b c$ & $5.46 \mathrm{bc}$ & $8.88 b c$ & $38.40 \mathrm{bc}$ \\
\hline $\mathrm{N}_{5} \mathrm{D}$ & $50.33 c$ & $79.00 \mathrm{bc}$ & $57.20 \mathrm{~cd}$ & $22.33 b c$ & $20.87 a b$ & $19.90 \mathrm{bc}$ & $3.62 \mathrm{~b}$ & $5.64 \mathrm{~b}$ & $9.26 \mathrm{~b}$ & $39.07 \mathrm{bc}$ \\
\hline Significance level & $* *$ & $*$ & $* *$ & $* *$ & $*$ & $*$ & $* *$ & $* *$ & $* *$ & $* *$ \\
\hline CV (\%) & 2.05 & 2.88 & 7.85 & 8.03 & 5.10 & 3.49 & 8.97 & 7.55 & 7.13 & 3.75 \\
\hline
\end{tabular}

Note: In a column, figures with same letter or without letter do not differ significantly as per DMRT; ${ }^{* \prime \prime}$ and ${ }^{\prime * * \prime}=$ Significant at 5 and $1 \%$, respectively and NS= Not significant; N0= No nitrogen, N1=Whole urea at land preparation @ 150kg/ha, N2=USG at LP @ 112 kg/ha, N3= USG @ $1.8 \mathrm{~g}$ (granule) per 4 hill $(112 \mathrm{~kg} / \mathrm{ha})$ at $10 \mathrm{DAT}, \mathrm{N} 4=50 \%$ urea $+2 \%$ urea spray at 30, 45 and $60 \mathrm{DAT}, \mathrm{N} 5=50 \%$ urea at land preparation + Magic growth spray at 30, 45 and 60 days. $W=$ wet seed bed and $D=$ Dry seed bed; CV (\%) = Percent coefficient of variation 
$112 \mathrm{~kg} / \mathrm{ha}$ USG at 10 DAT i.e., $\mathrm{N}_{3} \mathrm{~W}(\mathrm{p}<0.01)$ which was statistically similar with N1W (5.91 tha$\left.{ }^{1}\right)$ and N3D $\left(5.70\right.$ tha $\left.^{-1}\right)$. The lowest straw yield $\left(4.89 \mathrm{t} \mathrm{ha}^{-1}\right)$ was recorded in $\mathrm{N}_{0} \mathrm{D}$ (Table 5).

\section{Biological yield}

Significantly highest $(p<0.01)$ biological yield $\left(10.10\right.$ tha $\left.^{-1}\right)$ was found from USG $112 \mathrm{~kg} / \mathrm{ha}$ at $10 \mathrm{DAT}\left(\mathrm{N}_{3}\right)$ and the lowest value $\left(8.01 \mathrm{t} \mathrm{ha}^{-1}\right)$ regarding biological yield was found from the no urea treated plot ( $\mathrm{N}_{0}$; Table 3$)$. Biological yield was significantly influenced by seedling raising method (Table 4 ) where the maximum biological yield $\left(9.61 \mathrm{t} \mathrm{ha}^{-1}\right)$ was found in case of wet seed bed and the lowest biological yield $\left(8.74\right.$ tha $\left.^{-1}\right)$ was found from dry seed bed. Interaction effect between nitrogen management and seedling raising method was significant in respect of biological yield (Table 5). The highest biological yield $\left(10.67 \mathrm{t} \mathrm{ha}^{-1}\right)$ was recorded in $\mathrm{N}_{3} \mathrm{~W}$ treatment combination which was statistically at par with the treatment combinations $\mathrm{N}_{1} \mathrm{~W}, \mathrm{~N}_{2} \mathrm{~W}, \mathrm{~N}_{4} \mathrm{~W}, \mathrm{~N}_{5} \mathrm{~W}$ and $\mathrm{N}_{3} \mathrm{D}$ and the lowest biological yield $\left(7.45 \mathrm{t} \mathrm{ha}^{-1}\right)$ in the $\mathrm{N}_{0} \mathrm{D}$.

\section{Harvest index}

Nitrogen management produced significant differences $(p<0.01)$ in respect of harvest index (Table 3). The highest harvest index (41.65) was found from the $\mathrm{N}_{3}$ treatment and the lowest harvest index (35.32) was found from the control $\left(\mathrm{N}_{0}\right)$. Harvest index was also significantly influenced $(p<0.01)$ by the seedling raising method (Table 4). Higher harvest index (40.32) was found from the wet seed bed compared to dry seed bed (38.02). In considering the interaction effect, nitrogen management and seedling raising method significantly highest harvest index (43.17) was recorded in the $\mathrm{N}_{3} \mathrm{~W}(\mathrm{p}<0.01)$ which was statistically similar with the treatment combinations of $\mathrm{N}_{1} \mathrm{~W}$ and $\mathrm{N}_{5} \mathrm{~W}$. The lowest harvest index (34.40) was observed in case of $\mathrm{N}_{0} \mathrm{D}$ (Table 5)

\section{Conclusions}

The study concludes that seedlings raised in wet seedbed produced highest grain yield with the application of USG at 10 DAT and this was statistically similar to the whole urea application at land preparation along with wet seed bed and USG application along with dry seed bed. This suggests that wet seed bed preparation with whole urea application at land preparation or dry seed bed preparation with USG application at 10 DAT may be practiced for cost saving in tidal ecosystem of Bangladesh to avoid the complexity of USG application and scarcity of water for wet seed bed preparation.

\section{Acknowledgement}

The authors would like to express their thanks to the Ministry of Science and Technology, Bangladesh for providing financial support for conducting the experiment

\section{References}

Ahmed, M., Islam, Md. M \& Paul S.K. 2005: Effect of nitrogen on yield and other plant characters of local T. aman rice, var. jatai. Research journal of agriculture and biological sciences. 1(2): 158-161.

Bandaogo, A., Bidjokazo, F., Youl, S., Safo, E., Abaidoo, R. \& Andrews, O. 2015. Effect of fertilizer deep placement with urea supergranule on nitrogen use efficiency in Sourou 
Valley (Burkina Faso). Nutrient Cycling in Agroecosystems. 102: 79-89.

BBS (Bangladesh Bureau of Statistics) 2013: Yearbook of Agricultural Statistics of Bangladesh.

Ministry of Planning.Govt. of the People's Republic of Bangladesh, Dhaka. p. 136-140.

BRRI. Bangladesh Rice Research Institute, Government of the People's Republic of Bangladesh, Joydebpur, Gazipur; 2011.

Chaturvedi, I. (2005). Effect of nitrogen fertilizers on growth, yield and quality of hybrid rice (Oryza sativa). Journal of Central European Agriculture. 6(4): 611-618.

Das, K.P.B. 2011: Effect of nitrogenous fertilizer on the growth and yield of Boro rice cv. BRRI dhan45, MS Thesis, Dept. Agron., Bangladesh Agril. Univ., Mymensingh.

De Datta, S.K. 1989. Fertilizer management for efficient use in wetland rice soils. International Rice Research Institute. Soils and Rice. Los Banos Laguna, Philippines. Ministry of Planning, Government of the People's Republic of Bangladesh. IRRI Conference. International Rice Research Institute, P.O. Box. 933, Manila, Philippine.

Fageria, N.K. 2009. The Use of Nutrients in Crop Plants. CRC Press, Boca Raton, FL, pp. 20-50.

Fageria, N.K \& Santos, A.B. 2014. Lowland rice genotypes evaluation for nitrogen use. Journal of Plant Nutrition. 37 (9): 1410-1423.

FAO. Rice Market Monitor; Food and Agriculture Organization (FAO) of the United Nations: Rome, Italy, 2018.

Giroux, M. 1984. Effects d'application d'uree au sol et au feuillage sur le redement, le poids spe'cifique et la nutrition azote'e de la pomme de terre. Le Naturaliste canadien. 111: 157-166.

Gomez, K. A \& Gomez A. A. 1984: Statistical Procedure for Agricultural Research. 2nd ed. John Wiley and Sons. New York. 64.

Gregory, D.I., Haefele, S.M., Buresh, R.J. \& Singh U. 2010. Fertilizer use, markets, and management. In: Pandey, S., Byerlee, D., Dawe, D., Dobermann, A., Mohanty, S., Rozelle, S., Hardy, B. (Eds.), Rice in the Global Economy: Strategic research and policy issues for food security. Int. Rice Research Inst, Los Baños, Laguna, Philippines, pp. 231263.

Haider I.K. 2018. Appraisal of biofertilizers in rice: To supplement in organic chemical fertilizer. Rice Science. 25: 357-362.

Halder, A. 2013: Effect of PU, USG and NPK Briquette on Yield and Nitrogen Uptake by T. Aus Rice (BRRI dhan27). MS Thesis, Dept. soil sci., Bangladesh Agril. Univ., Mymensingh.

Hasegawa, T., Koroda, Y \& Eligman, N.G. 1994. Response to spikelet number of plant nitrogen concentration and dry weight in paddy. Agronomy Journal. 86: 673-676.

Hassan, M.S., Khair, A., Haque, M.M., Azad, A.K \& Hamid, A. 2009. Genotypic variation in traditional rice varieties for chlorophyll content, SPAD value and nitrogen use efficiency. Bangladesh Journal of Agricultural Research. 34 (3): 505-515.

Hossain, S.M.A \& Islam, M.S. 2008: Fertilizer Management in Bangladesh. Advances in Agronony Research in Joydebpur, Gazipur. p. 48-54.

Ilaga, L. G. \& Dayag, A. M. 1989. Study on the use of four locally processed organic fertilizer in combination with chemical fertilizer on lowland rice. $R$ and D Philippines (Philippines). 
Lam H.M, Coschigano, K.T., Oliveira, I.C., Melo-Oliveira, R. \& Coruzzi G.M. 1996. The molecular-genetics of nitrogen assimilation into amino acids in higher plants. Plant Physiology and Plant Molecular Biology. 47: 569-593.

Liu, X., Wang, H., Zhou, J., Hu, F., Zhu, D., Chen, Z. \& Liu, Y. 2016. Effect of N Fertilization Pattern on Rice Yield, N Use Efficiency and Fertilizer-N Fate in the Yangtze River Basin, China. PLoS ONE 11(11): e0166002. doi:10.1371/journal.pone.0166002

Miah., M.M.M., Shah, A. L. \& Ishaque M. 2006. Nutrient management for different rice ecosystem. In proceeding of the workshop on modern Rice Cultivation in Bangladesh. 12-21 April 2004. Bangladesh Rice Research Institute, Gazipur 1701, Bangladesh. 18283.

Millard, P \& Robinson D. 1990. Effect of the timing and rate of nitrogen-fertilization on the growth and recovery of fertilizer nitrogen within the potato (Solanum tuberosum L.). Fertilizer research. 21: 133-140.

Mohanty, S.K., Singh, U., Balasubramanian, V \& Jha K. P. 1999. Nitrogen deep-placement technologies for productivity, profitability, and environmental quality of rainfed lowland rice systems. Nutrient Cycling in Agroecosystems. 53:43-57.

Nicoulaud, B.A.L \& Bloom A. J. 1996. Absorption and assimilation of foliarly applied urea in tomato. Journal of the American Society for Horticultural Science. 121: 1117-1121.

Nori H, Halim R. A \& Ramlan M. F. 2008: Effect of nitrogen fertilizer management practice on the yield and straw nutritional quality of commercial Rice Varieties. Malaysian Journal of Mathematical Sciences. 2(2): 61-71.

Parvin, S. 2012: Improving yield of T. Aman rice (cv. BRRI dhan52) through integrated use of nitrogen. MS Thesis, Dept.Agron., Bangladesh Agril. Univ., Mymensingh. p. 23-33.

Rahman, M., Sarker, M. N. H., Akter, F. M. F \& Masood M. M. 2005: Comparative yield performance of two high yielding rice varieties to different nitrogens levels. Bangladesh Journal of Crop Science. 16(1): 73-78.

Rahman, M. M., Samanta, S. C., Rashid, M. H., Abuyusuf, M., Hassan, M. Z \& Sukhi K. F. N. 2016. Urea super granule and NPK briquette on growth and yield of different varieties of aus rice in tidal ecosystem. Asian Journal of Crop Science. 8: 1-12.

Rajarathinam, P \& Balasubramaniyan, P. 1999: Effect of plant population and nitrogen on yield attributes and yield of rice (Oryza sativa). Indian Journal of Agronomy. 44(4): 717721.

Rochette, P., Angers, D.A., Chantigny, M.H., Gasser, M.O., Mac-Donald, J.D., Pelster, D.E \& Bertrand, N. 2013. Ammonia volatilization and nitrogen retention: How deep to incorporate urea? J. Journal of environmental quality. 42: 1635-1642.

Russel, D.F. 1986: MSTAT-C package program. Crop and Soil Sci. Dept, Michigan State Uni, USA.

Savant, N.K. \& Stangel P. J. 1990. Deep placement of urea supergranules in transplanted rice: Principles and practices. Fertilizer Research. 25:1-83.

Shah, A.L., Sarker, A. B. S., Islam, S. M. M \& Mridha A. J. 2013: Deep placement of NPK briquette: Environment friendly technology for rice production. Paper presented at the 
National Workshop on deep placement of NPK briquette, held at BARC, Dhaka on March 28, 2013 in collaboration with IFDC.

Tahura, S. 2011: Effect of PM and Nitrogenous Fertilizer on the Growth and Yield of Transplant Aman Rice, MS Thesis, Depart. Agron., Bangladesh Agril. Univ., Mymensingh.

UNB. United News of Bangladesh. Govt launches Tk $336 \mathrm{~m}$ incentive to boost Aus production. The Financial Express. http://www. thefinancialexpress-bd.com/2016/03/27/23283 (2016). Accessed 02 Oct 2017.

Wittwer, S.H., Bukovac, M. J \& Tukey H. B. 1963. Advances in foliar feeding of plant nutrients. In MH McVickar, ed, Fertilizer Technology and Usage. Soil Science Society of America, Madison, WI, pp: 429-455.

Xiong, J., Ding, C. Q., Wei, G. B., Ding, Y.F \& Wang S. H. 2013. Characteristic of Dry-Matter Accumulation and Nitrogen-Uptake of Super-High-Yielding Early Rice in China. Agronomy Journal. 105(4):1142 \pm 50 .

Yoshida, S., Cock, J. H \& Parao F. T. 1972. Physiological aspects of high yield. Int. Rice Res. Inst. Rice breeding, pp. 455-469. 